\title{
Anestesia em Paciente Portadora de Doença de Moyamoya. Relato de Caso *
}

\section{Anesthesia in Patient with Moyamoya Disease. Case Report}

Adriano Bechara de Souza Hobaika ${ }^{1}$; Vera Coelho Teixeira, TSA ${ }^{2}$;

Marcos Guilherme Cunha Cruvinel, TSA ${ }^{3}$; Alexandre Cordeiro Ulhoa ${ }^{4}$

\section{RESUMO}

Hobaika ABS, Teixeira VC, Cruvinel MGC, Ulhoa AC - Anestesia em Paciente Portadora de Doença de Moyamoya. Relato de Caso

JUSTIFICATIVA E OBJETIVOS: A doença de moyamoya é uma vasculopatia cerebral progressiva rara, mais freqüentemente diagnosticada em populações asiáticas, mas que também vem sendo identificada no Brasil. Durante a sua vida, pacientes portadores desta doença podem ser submetidos aos mais variados tipos de procedimentos cirúrgicos. O anestesiologista deve entender a fisiopatologia da doença e instituir as medidas peri-operatórias mais adequadas, no intuito de melhorar o prognóstico destes pacientes.

RELATO DO CASO: Paciente do sexo feminino, 22 anos, com insuficiência renal crônica, portadora da doença de moyamoya, submetida à intervenção cirúrgica para instalação de fístula arteriovenosa. A anestesia foi induzida com fentanil, propofol e atracúrio e mantida com sevoflurano. Durante o procedimento, a paciente foi mantida em normocapnia e normotermia. A extubação foi realizada e a paciente transferida à sala de recuperação pós-anestésica sem complicações.

CONCLUSÕES: Este artigo apresenta os cuidados anestésicos dispensados a uma paciente portadora da doença de moyamoya.

Unitermos: ANESTESIA, Geral: inalatória; DOENÇAS: moyamoya

\section{SUMMARY}

Hobaika ABS, Teixeira VC, Cruvinel MGC, Ulhoa AC - Anesthesia in Patient with Moyamoya Disease. Case Report

BACKGROUND AND OBJECTIVES: Moyamoya disease is an uncommon progressive cerebral vasculopathy, more frequently diagnosed among Asian individuals, but which has also been described in Brazil. Moyamoya patients may be submitted to different surgical procedures throughout their lives. Anesthesiologists must understand the pathophysiology of the disease and institute adequate perioperative measures to improve patients' prognosis.

CASE REPORT: Female patient, 22 yr-old, chronic renal failure, with moyamoya disease, scheduled for surgical arterial-venous fistula installation. Anesthesia was induced with fentanyl, propofol and atracurium and maintained with sevoflurane. Patient was maintained in normocapnia and normothermia throughout the procedure. Patient was extubated and transferred to the post-anesthetic care unit without complications.

CONCLUSIONS: This article describes the anaesthetic care of a moyamoya disease patient.

Key Words: ANESTHESIA, General: inhalational; DISEASES: moyamoya

\section{INTRODUÇÃO}

A doença de moyamoya é uma vasculopatia encefálica progressiva não inflamatória, não aterosclerótica e não amiloidótica, que acomete mais freqüentemente indivíduos japoneses e seus descendentes, apesar de ser descrita em

\footnotetext{
* Recebido do (Received from) Hospital Felício Rocho, Belo Horizonte, $M G$

1. Ex-ME $E_{2}$ em Anestesiologia do CET/SBA do Hospital Felício Rocho

2. Coordenadora do CET/SBA do Hospital Felício Rocho

3. Especialista em Clínica Médica; Anestesiologista do Hospital Life Center

4. Neuroradiologista do Hospital Felício Rocho e do Hospital das Clínicas da UFMG
}

Apresentado (Submitted) em 27 de julho de 2004

Aceito (Accepted) para publicação em 27 de janeiro de 2005

Endereço para correspondência (Correspondence to)

Dr. Adriano Bechara de Souza Hobaika

Rua Elza Brandão Rodarte, 137/1602 Belvedere

30320-630 Belo Horizonte, MG

E-mail: hobaika@globo.com

(C) Sociedade Brasileira de Anestesiologia, 2005 todo o mundo. É uma condição rara e caracterizada por estenose ou oclusão bilateral da porção terminal da artéria carótida interna e/ou das porções proximais das artérias cerebrais anteriores e/ou cerebrais médias. O diagnóstico é confirmado por angiografia cerebral, onde os vasos patológicos se apresentam semelhantes à "nuvem da fumaça de cigarro", daí a origem do termo japonês moyamoya ${ }^{1,2}$. Malformação vascular congênita ou arterite adquirida podem estar envolvidas na etiologia desta doença. Exames de autópsia evidenciam redução do calibre dos vasos com fibrose, por aumento da espessura da íntima e por degeneração da lâmina elástica interna.

Existem dois picos etários de aparecimento dos sintomas: na primeira e na terceira décadas. Em crianças, a doença de moyamoya se manifesta principalmente por fenômenos neurológicos isquêmicos como paresia, alterações sensoriais, cefaléia, convulsão e movimentos involuntários; na idade adulta, se apresenta mais comumente por hemorragia intracraniana. Ainda podem estar presentes convulsões, fraqueza muscular e redução do nível de consciência ${ }^{3}$. Com a evolução da doença, o quociente de inteligência pode se reduzir em até $60 \%$, em um período de 5 a 9 anos $^{4}$. Freqüentemente, 
esta doença está associada a outras morbidades como asma, síndrome de Down e hipotireoidismo.

Algumas técnicas cirúrgicas de neovascularização têm sido utilizadas com o intuito de aumentar o fluxo da circulação colateral intracraniana, através de bypass extracraniano-intracraniano e têm apresentado bons resultados na prevenção dos episódios isquêmicos em crianças ${ }^{5,6}$. Devido aos eventos hemorrágicos, estes pacientes também podem ser submetidos à drenagem ventricular, drenagem de hematoma, pinçamento de aneurisma e derivação ventriculoperitoneal ${ }^{7}$.

\section{RELATO DO CASO}

Paciente do sexo feminino, 22 anos, 41 kg, não-oriental, com diagnóstico de doença de moyamoya há 16 anos, submetida à intervenção cirúrgica para realização de fístula arteriovenosa no membro superior direito. Apresentava crises convulsivas freqüentes, retardo mental e atrofia de membros inferiores. Portadora de hipertensão arterial e insuficiência renal crônica. Em uso oral regular de fenitoína (anticonvulsivante) e codergocrina (vasodilatador periférico).

Na véspera do procedimento, através de cateter de duplo lúmen, foram administrados $600 \mathrm{~mL}$ de concentrado de hemácias, durante a sessão de hemodiálise. Exames pré-operatórios: hemoglobina $11,0 \mathrm{mg} / \mathrm{dL}$, potássio sérico $4,9 \mathrm{mmol} / \mathrm{L} \mathrm{e}$ atividade da protrombina de $71 \%$.

A paciente foi monitorizada com oxímetro de pulso, ECG, aparelho para medida automática de pressão arterial não-invasiva, capnografia e termômetro, posicionado na nasofaringe. Aanestesia foi induzida com fentanil $(0,25 \mathrm{mg})$, propofol (150 mg) e atracúrio (25 mg), para facilitar a intubação traqueal, e mantida com administração inalatória de sevoflurano (2\% a 3\%). A ventilação mecânica dos pulmões foi ajustada para obter uma $\mathrm{P}_{\mathrm{ET}} \mathrm{CO}_{2}$ próxima de $36 \mathrm{mmHg}$. A paciente foi mantida aquecida através de circulação forçada de ar quente e, líquidos venosos foram infundidos em temperatura morna. O procedimento durou 72 minutos, a extubação foi realizada sem complicações e a paciente foi transferida para sala de recuperação pós-anestésica.

\section{DISCUSSÃO}

Em 1997, foram registrados no Japão, aproximadamente 3800 casos de doença de moyamoya ${ }^{5}$, em que fatores genéticos parecem estar envolvidos ${ }^{8,9}$. Em um estudo cooperativo recente, realizado na Coréia, mais de 330 pacientes portadores da doença foram identificados ${ }^{3}$. No Brasil existem aproximadamente 21 casos publicados até 1999, o que provavelmente é um número infra-estimado ${ }^{10}$.

A conduta anestésica destes pacientes deve priorizar a manutenção do fluxo sangüíneo encefálico, pois estados peri-operatórios desfavoráveis podem desencadear eventos neurológicos negativos. Manter a normocapnia é fundamental, pois existem evidências de que tanto a hipocapnia como a hipercapnia reduzem o fluxo sangüíneo encefálico nestes pacientes ${ }^{11}$. A ventilação controlada dos pulmões apresenta vantagens no estabelecimento da normocapnia, pois permite alterações mensuráveis dos parâmetros ventilatórios. Fatores como hipovolemia e hipotensão arterial também foram identificados na gênese da isquemia peri-operatória e devem ser evitados ${ }^{12}$. Idealmente, deve ser mantido um estado de hipervolemia nestes pacientes e um debito urinário próximo de $2 \mathrm{~mL} \cdot \mathrm{kg}^{-1} \cdot \mathrm{h}^{-1}$. Os valores de hematócrito não devem estar acima do normal, pois podem precipitar isquemia encefálica e a anemia deve ser corrigida no pré-operatório, a fim de aumentar o transporte de oxigênio. Há a sugestão de que os valores de hematócrito devem permanecer entre $30 \%$ e $42 \%$, com uma leve hemodiluição, o que pode ser benéfico pela redução da viscosidade sangüínea ${ }^{13}$. Normotermia também é recomendada, pois foi verificado que pacientes portadores da doença de moyamoya podem apresentar vasoespasmo na vigência de hipotermia, enquanto que a hipertermia pode também precipitar fenômenos isquêmicos ${ }^{14}$. Em crianças, a isquemia decorrente de hiperventilação peri-operatória causada pelo choro é uma complicação comum e importante e suas principais causas são a ansiedade e a dor pós-operatória. Sedação pré-operatória eficaz e controle álgico rigoroso devem ser implementados de rotina, sendo recomendado que se mantenha o acesso venoso pelo menos por uma semana ${ }^{15}$. Em relação à administração de anestésicos voláteis, a opção pelo isoflurano, assim como pelo sevoflurano, parece segura, por proporcionar um grau de proteção encefálica significativa durante a isquemia temporária ${ }^{16-18}$.

A espectroscopia infravermelha é um método não-invasivo de monitorização transcraniana contínua da oxigenação encefálica. Sua utilização deve ser feita quando há risco de isquemia encefálica. Nestas situações, a monitorização bilateral deve ser utilizada ${ }^{19}$. Os pacientes com doença de moyamoya são mais susceptíveis à isquemia encefálica, portanto, a monitorização da oximetria transcraniana pode ser muito útil.

A paciente ainda apresentava insuficiência renal crônica, o que impediu o estabelecimento da hipervolemia e hemodiluição, além de não ser possível medir o débito urinário. A normocapnia foi mantida com a ventilação mecânica dos pulmões e o ajuste adequado da $\mathrm{P}_{\mathrm{ET}} \mathrm{CO}_{2}$ à capnografia. A hipotermia foi controlada com infusão venosa de solução fisiológica a $0,9 \%$ morna e circulação forçada de ar quente sobre o corpo da paciente.

A anestesia - regional ou local - associada à sedação, poderia ser utilizada na paciente, porém, devido ao grau de retardo mental e agitação psicomotora, optou-se por anestesia geral com indução venosa, o que proporcionou um curso anestésico suave, além de permitir um controle adequado da $\mathrm{P}_{\mathrm{ET}} \mathrm{CO}_{2}$

$\mathrm{Na}$ doença de moyamoya, apesar de algumas condutas anestésicas estarem estabelecidas, todas as comorbidades do paciente devem ser avaliadas criteriosamente pelo anestesiologista e condutas peri-operatórias específicas devem ser estabelecidas para cada caso. 


\section{Anesthesia in Patient with Moyamoya Disease. Case Report}

Adriano Bechara de Souza Hobaika, M.D.; Vera Coelho Teixeira, TSA, M.D.; Marcos Guilherme Cunha Cruvinel, TSA, M.D.; Alexandre Cordeiro Ulhoa, M.D.

\section{INTRODUCTION}

Moyamoya disease is a non-inflammatory, non-atherosclerotic and non-amyloidal cerebral vasculopathy more often affecting Japanese and descendents, although being worldwide described. It is an uncommon condition characterized by bilateral stenosis or occlusion of the terminal portion of the internal carotid and/or proximal portions of anterior cerebral or median cerebral arteries. Diagnosis is confirmed by brain angiography, where pathological vessels are presented similar to "cigarette smoke cloud", hence the origin of the Japanese world moyamoya ${ }^{1,2}$. Congenital vascular malformation or acquired arteritis may be involved in the etiology of the disease. Autopsies have revealed decreased vessel size with fibrosis by increased intima thickness and internal elastic lamina degeneration.

There are two age peaks for the appearance of symptoms: the first and the third decades. In children, moyamoya disease is primarily manifested by ischemic neurological phenomena, such as paresis, sensory changes, headache, seizure and involuntary movements; in adults it is more commonly manifested as intracranial hemorrhage ${ }^{3}$. With the evolution of the disease, IQ may be decreased in up to $60 \%$ in a period of 5 to 9 years ${ }^{4}$. In general, the disease is associated to other morbidities, such as asthma, Down syndrome and hypothyroidism.

Some surgical revascularization techniques have been used aiming at increasing intracranial collateral circulation flow through extracranial - intracranial bypass, and have shown good results in preventing ischemic episodes in children ${ }^{5,6}$. Due to hemorrhagic events, these patients may also have to be submitted to ventricular drainage, hematoma drainage, aneurysm clipping and ventriculoperitoneal shunt ${ }^{7}$.

\section{CASE REPORT}

Female patient, 22 years old, $41 \mathrm{~kg}$, not Asian, with moyamoya disease diagnosed 16 years ago, submitted to surgical procedure for arteriovenous fistula installation in right upper limb. Patient presented frequent seizures, mental retardation and lower limbs atrophy, in addition to hypertension and chronic renal failure. Patient was under regular phentoine (anticonvulsant) and codergocrine (peripheral vasodilator).

The day before surgery, $600 \mathrm{~mL}$ of packed red cells were administered via the double- lumen catheter during dialysis. Preoperative tests included hemoglobin $11.0 \mathrm{mg} / \mathrm{dL}$, serum potassium $4.9 \mathrm{mmol} / \mathrm{L}$ and prothrombin activity $71 \%$.
Monitoring consisted of pulse oximetry, ECG, noninvasive automatic blood pressure, capnography and nasopharyngeal thermometer. Anesthesia was induced with fentanyl (0.25 mg), propofol (150 mg) and atracurium (25 mg), and was maintained with inhalational sevoflurane (2\% to $3 \%)$.

Mechanical ventilation was adjusted to keep $\mathrm{P}_{\mathrm{ET}} \mathrm{CO}_{2}$ around $36 \mathrm{mmHg}$. The patient was warmed through forced warm air circulation device and heated intravenous fluids. Procedure lasted 72 minutes and extubation was achieved without complications. Patient was transferred to the PACU.

\section{DISCUSSION}

Approximately 3800 cases of moyamoya disease were reported in $1997^{5}$ in Japan, where genetic factors seem to be involved $^{8,9}$. In a recent cooperative study performed in Korea, more than 330 moyamoya disease patients were identified ${ }^{3}$. In Brazil there are approximately 21 cases published until 1999 , which is probably an underestimated figure ${ }^{10}$.

Anesthetic management of such patients should prioritize brain blood flow maintenance because unfavorable perioperative states may trigger negative neurological events. Normocapnia is critical because there are evidences that both hypocapnia and hypercapnia decrease brain blood flow in these patients ${ }^{11}$. Controlled ventilation is advantageous to establish normocapnia since it allows for measurable changes in ventilatory parameters.

Factors such as hypovolemia and hypotension have been also identified in the genesis of perioperative ischemia and should be prevented ${ }^{12}$. Ideally, these patients should be kept hypervolemic with urinary output close to $2 \mathrm{~mL} \cdot \mathrm{kg}^{-1} \cdot \mathrm{h}^{-1}$. Hematocrit values should not be above normal because they may trigger cerebral ischemia, and anemia should be corrected in the preoperative period to maximize oxygen transportation. It has been suggested that hematocrit values should remain between $30 \%$ and $42 \%$ with mild hemodilution, which may be beneficial for decreasing blood viscosity ${ }^{13}$. Normothermia is also recommended because it has been observed that moyamoya disease patients may present vasospasm in the presence of hypothermia, while hyperthermia may also trigger ischemic events ${ }^{14}$. In children, ischemia caused by perioperative hyperventilation due to crying is a common and major complication primarily caused by anxiety and postoperative pain. Effective preoperative sedation and strict pain control should be routinely implemented and it is recommended that venous access be left in place for at least one week ${ }^{15}$. Regarding volatile anesthetics, isoflurane and sevoflurane seem to be safe options for providing significant cerebral protection during transient ischemia $^{16-18}$.

Infrared spectroscopy is a noninvasive method for continuous transcranial monitoring of cerebral oxygenation. It should be used in case of risk of cerebral ischemia. In these situations, bilateral monitoring is recommended ${ }^{19}$. Moyamoya disease patients are more susceptible to cerebral ischemia, so transcranial oximetry monitoring may be very useful. 
Patient had also chronic renal failure what prevented the establishment of hypervolemia and hemodilution, in addition to making impossible to measure urinary output. Normocapnia was maintained with mechanical ventilation and adequate $\mathrm{P}_{\mathrm{ET}} \mathrm{CO}_{2}$ adjustment to capnography. Hypothermia was controlled with warmed $0.9 \%$ saline infusion and forced warm air circulation over patient's body.

Regional or local anesthesia associated to sedation could have been used in the patient, however due to the level of mental retardation and psychomotor agitation, we decided for general intravenous anesthesia which provided smooth anesthesia in addition to allowing adequate $\mathrm{P}_{\mathrm{ET}} \mathrm{CO}_{2}$ control. Although there are some established anesthetic approaches for moyamoya disease, all co-morbidities should be thoroughly evaluated by the anesthesiologist and specific perioperative approaches should be determined on a case-by-case basis.

\section{REFERÊNCIAS - REFERENCES}

01. Fukui M, Kono S, Sueishi K et al - Moyamoya disease. Neuropathology, 2000;20:S61-64.

02. Yilmaz EY, Pritz MB, Bruno A et al - Moyamoya: Indiana University Medical Center experience. Arch Neurol, 2001;58: 1274-1278.

03. Han DH, Kwon O, Byun BJ et al - A co-operative study: clinical characteristics of 334 Korean patients with moyamoya disease treated at neurosurgical institutes (1976-1994). Acta Neurochir, 2000;142:1263-1274.

04. Matsushima Y, Aoyagi M, Nariai T et al - Long-term intelligence outcome post-encephalo-duro-arterio-synangiosis in childhood moyamoya patients. Clin Neurol Neurosurg, 1997;99: S147-S150.

05. Fukui M - Guidelines for the diagnosis and treatment of spontaneous occlusion of the circle of Willis ('moyamoya' disease). Research Committee on Spontaneous Occlusion of the Circle of Willis (Moyamoya Disease) of the Ministry of Health and Welfare, Japan. Clin Neurol Neurosurg, 1997;99@Suppl2): S238-S240.

06. Houkin K, Kamiyama H, Takahashi A et al - Combined revascularization surgery for childhood moyamoya disease: STA-MCA and encephalo-duro-arterio-myo-synangiosis. Childs Nerv Syst, 1997;13:24-29.

07. Yoshida Y, Yoshimoto T, Shirane R et al - Clinical course, surgical management, and long-term outcome of moyamoya patients with rebleeding after an episode of intracerebral hemorrhage: An extensive follow-up study. Stroke, 1999;30:2272-2276.

08. Ikeda H, Sasaki T, Yoshimoto T et al - Mapping of a familial moyamoya disease gene to chromosome 3p24.2-p26. Am J Hum Genet, 1999;64:533-537.

09. Inoue TK, Ikezaki K, Sasazuki T et al - Linkage analysis of moyamoya disease on chromosome 6. J Child Neurol, 2000;15: 179-182.

10. Franco CM, Fukujima MM, de Oliveira Rde C et al - Moyamoya disease. Report of three cases in Brazilian patients. Arq Neuropsiquiatr, 1999;57:371-376.
11. Yusa T, Yamashiro K - Local cortical cerebral blood flow and response to carbone dioxide during anesthesia in patients with moyamoya disease. J Anesth, 1999;13:131-135.

12. Iwama T, Hashimoto N, Tsukahara T et al - Perioperative complications in adult moyamoya disease. Acta Neurochir, 1995;132: 26-31.

13. Sato K, Shirane R, Yoshimoto T - Perioperative factors related to the development of ischemic complications in patients with moyamoya disease. Childs Nerv Syst, 1997;13:68-72.

14. Malley RA, Frost EAM - Moyamoya disease. Pathophysiology and anesthetic management. J Neurosurg Anesthesiol, 1989;1: 110-114.

15. Nomura S, Kashiwagi S, Uetsuka S et al - Perioperative management protocols for children with moyamoya disease. Childs Nerv Syst, 2001;17:270-274.

16. Newman B, Gelb AW, Lam AM - The effect of isoflurane induced hypotension on cerebral blood flow and cerebral metabolic rate for oxygen in humans. Anesthesiology, 1986;64:307-310.

17. Summors AC, Gupta AK, Matta BF - Dynamic cerebral autoregulation during sevoflurane anesthesia: a comparison with isoflurane. Anesth Analg, 1999;88:341-345.

18. Machado SB, Mendes FF, Angelini AC - Doença de moyamoya e anestesia com sevoflurano fora do centro cirúrgico. Relato de caso. Rev Bras Anestesiol, 2002;52:344-347.

19. Kurth CD, Uher B - Cerebral hemoglobin and optical pathlength influence near-infrared spectroscopy measurement of cerebral oxygen saturation. Anesth Analg, 1997;84:1297-1305.

\section{RESUMEN}

Hobaika ABS, Teixeira VC, Cruvinel MGC, Ulhoa AC - Anestesia en Paciente Portadora de Enfermedad de Moyamoya. Relato de Caso

JUSTIFICATIVA Y OBJETIVOS: La enfermedad de moyamoya es una vasculopatia cerebral progresiva rara, más frecuentemente diagnosticada en individuos asiáticos, y que también viene siendo identificada en Brasil. Durante su vida, pacientes portadores de esta enfermedad pueden ser sometidos a los más variados tipos de procedimientos quirúrgicos. El anestesiologista debe entender la fisiopatología de la enfermedad e instituir las medidas peri-operatorias más adecuadas, en el designio de mejorar el pronóstico de estos enfermos.

RELATO DEL CASO: Paciente del sexo femenino, 22 años, insuficiencia renal crónica, portadora de la enfermedad de moyamoya, sometida a intervención quirúrgica para la instalación de fístula arteriovenosa. La anestesia fue inducida con fentanil, propofol y atracúrio y mantenida con sevoflurano. Durante el procedimiento, la paciente fue mantenida en normocapnia y normotermia. La extubación fue realizada y la paciente transferida a la sala de recuperación pos-anestésica sin complicaciones.

CONCLUSIONES: Este artículo presenta los cuidados anestésicos dados a una paciente portadora de la enfermedad de moyamoya. 